\title{
Prevelance of Leiomyoma in South Eastern Tertiary Hospital of Nigeria From 2005-2012.
}

\author{
Nnoli M.A ${ }^{1}$,Nwabuko C.O ${ }^{2}$,Ebughe G.A ${ }^{3}$, Nkwo E.C. ${ }^{4}$ \\ University of Calabar, Dept of Pathology, Calabar. ${ }^{1,3}$ \\ Federal Medical Centre, Dept of Haemato-Pathology, Umuahia. ${ }^{2}$ \\ Federal Medical centre,Dept of Obstretics\& Gynaecology,Umuahia ${ }^{4}$
}

\begin{abstract}
Aim \& Objectives: This is to determine the age range thatare vulnerable to this lesion with view of evaluating possible cause of infertility.

Materials \& Methods: A cross sectional study of post-surgical uterine samples, histologically reported leiomyoma totaling 557 from 2005-2012 were collected from the departmental result records. The whole samples were seen to be females and analysis done per each year using SPSS(statistical package for the social sciences) version 16.

Results: The most prevalent age range of occurrence throughout the study was-age range of 30-40 years and this is closely followed by 40-50 years. These ranges fall into the fertility years of most African women hence the search for effective treatment and cause of infertility.

Conclusion: We were able to actualize that at early ages and late-post menopausal the number of lesion appears to be minimal.

Keywords: leiomyoma,Histology, infertility
\end{abstract}

\section{Introduction:}

Uterine leiomyoma ( fibroids,Myomas) are among the most common tumors of female reproductive tract and occur within the premenopausal women. ${ }^{1}$ They are benign monoclonal tumors of uterus composed of spindle shaped smooth muscle fibres with extracellular matrix of collagen,fibronectin and proteoglycan. ${ }^{2}$ There is preposition of genetic disposition, with 2-3 fold of risk increase in affectation. ${ }^{3}$ They may be seen in single but usually in clusters. Are more common in women of African descent and in nulliparity women;as are often seen in ages of 30-45 years. ${ }^{4}$ This benign,solid tumors of female genital tract though assymptomatic are of hormone dependent. They are affected by level of oestrogen,progesterone and a variety of growth factors. ${ }^{5,6}$ The role of gonadal steroids is believed to be the fact that fibroids are rarely seen in children as they tend to regress after menopause. These benign lesion can grow within the muscle layers of the uterus ( serosal, submucosal or intramural), as intrauterine fibroid . At times they may be seen outside the uterus as pedunculated stalk. ${ }^{7}$ Uterine leiomyoma can be symptomatic or asymptomatic. The cardinal clinical presentations include: menorrhagia, meterrohagia, infertility, pains, pressure symptomsand repeated abortions. ${ }^{6}$

Although, the etiology of this lesion is unknown but is leading indication for hysterectomy in USA. It is about four times higher in blacks when compared with whites. However, the women who suffer from this disease always desire to maintain fertility since most are young women. This drives them to seek for treatment modalities but this choice of treatment is often limited. At the moment there is no effective long term medicinal treatment for uterine fibroids. Surgical approach is still the gold standard for treatment. However, oral administered medications are now coming up.

Ogedengbeo.k et al found that 1 in every 5 women of child bearing ages of over 30 years have fibroids. ${ }^{9}$ AkinyemiB.O found that $20-30 \%$ of women of this age harbor uterine fibroids thus accounting to $3.2-$ $7.6 \%$ of new gynaecological cases and $68.1 \%$ of hysterectomies. ${ }^{10-12}$ Durhan $\mathrm{N}$ et al found that uterine myomas,though benign,solid,pelvic tumors in women occur in $20-40 \%$ of this group of women at their reproductive age since this forms the basis of hysterectomy. However, other modalities in treatment like uterine embolization for those with large symptomatic myomas who are poor surgical risks/wishes not to do surgery. Also pre-operative gonadotropin -releasing hormone analog treatment before myomectomy as this have decreased the size and vascularity of the myomas;though it has demerits of hardening of capsules leading to difficulty in resecting. ${ }^{13}$ The embolization is a percutaneous procedure that results to occlusion of perifibroid vessels and ischaemic infarction of fibroid thus shrinking the fibroid within months to years. ${ }^{14,15}$ However, incomplete infracted fibroids may regenerate and develop over time. ${ }^{15,16}$ Incomplete infracted uterus after embolization will have hyalne necrosis or coagulative necrosis of the tumor mass. ${ }^{17,18}$

Transcervical expulsion of fibroid occurs in 2.2-7.7\% of women after embolization,in few cases surgical extraction may be needed. ${ }^{19}$ This explusion could be associated with endometrial infection as this occurs in about $5.9 \%$ and $2.6 \%$ leading to major infections that ends up with surgery. ${ }^{19}$ This is why its mandatory to 
routinely give prophylactic antibiotics during embolization as to reduce risk of infections. However, transient or permanent amenorrhea has been seen with result of incomplete non target embolization of ovaries leading to atrophy of the ovaries. ${ }^{19}$ These may result to not only imparing the lining of the endometrium and embryo implantation but also affecting cause of pregnancy. Other abnormalities could exist such as placenta praevia or accrete which will lead to increased risk of bleeding and that may result to hysterectomy. ${ }^{20}$

In our own case, it is pertinent to note surgical approach-hysterectomy and myomectomy still stands as main and definitive mains of treatment. This is equally the findings with studies of Lunsden et al, ${ }^{21}$ Omole $\mathrm{A}$ et al and Emebolu J.O respectively. They hold the view that hysterectomy is a definitive while myomectomy may remove fibroids for women under 40 years with low parity and the great desire to maintain fertility. ${ }^{24-26}$ In our study we tend to evaluate the prevalence of this benign,solid tumors and to know which age range is mostly affected as a factor of infertility.

\section{Materials \& Method:}

A cross sectional study of 557 post-surgical operated leiomyomata from 2005 -2012 was undertaken. This was based on samples sent in our unit and diagnosed histologically. All data were obtained from result register for all the years of study. They data were analyzed using SPSS version 16.

\section{Results:}

\begin{tabular}{|c|c|c|c|c|c|}
\hline & & Frequency & Percent & Valid Percent & $\begin{array}{l}\text { Cumulative } \\
\text { Percent }\end{array}$ \\
\hline \multirow[t]{6}{*}{ Valid } & $20-30$ years & 4 & 4.0 & 16.0 & 16.0 \\
\hline & $30-40$ years & 10 & 10.0 & 40.0 & 56.0 \\
\hline & $40-50$ years & 8 & 8.0 & 32.0 & 88.0 \\
\hline & $50-60$ years & 2 & 2.0 & 8.0 & 96.0 \\
\hline & $60-70$ years & 1 & 1.0 & 4.0 & 100.0 \\
\hline & Total & 25 & 25.0 & 100.0 & \\
\hline Missing & System & 75 & 75.0 & & \\
\hline Total & & 100 & 100.0 & & \\
\hline
\end{tabular}

Prevelance of Leiomyoma in 2005

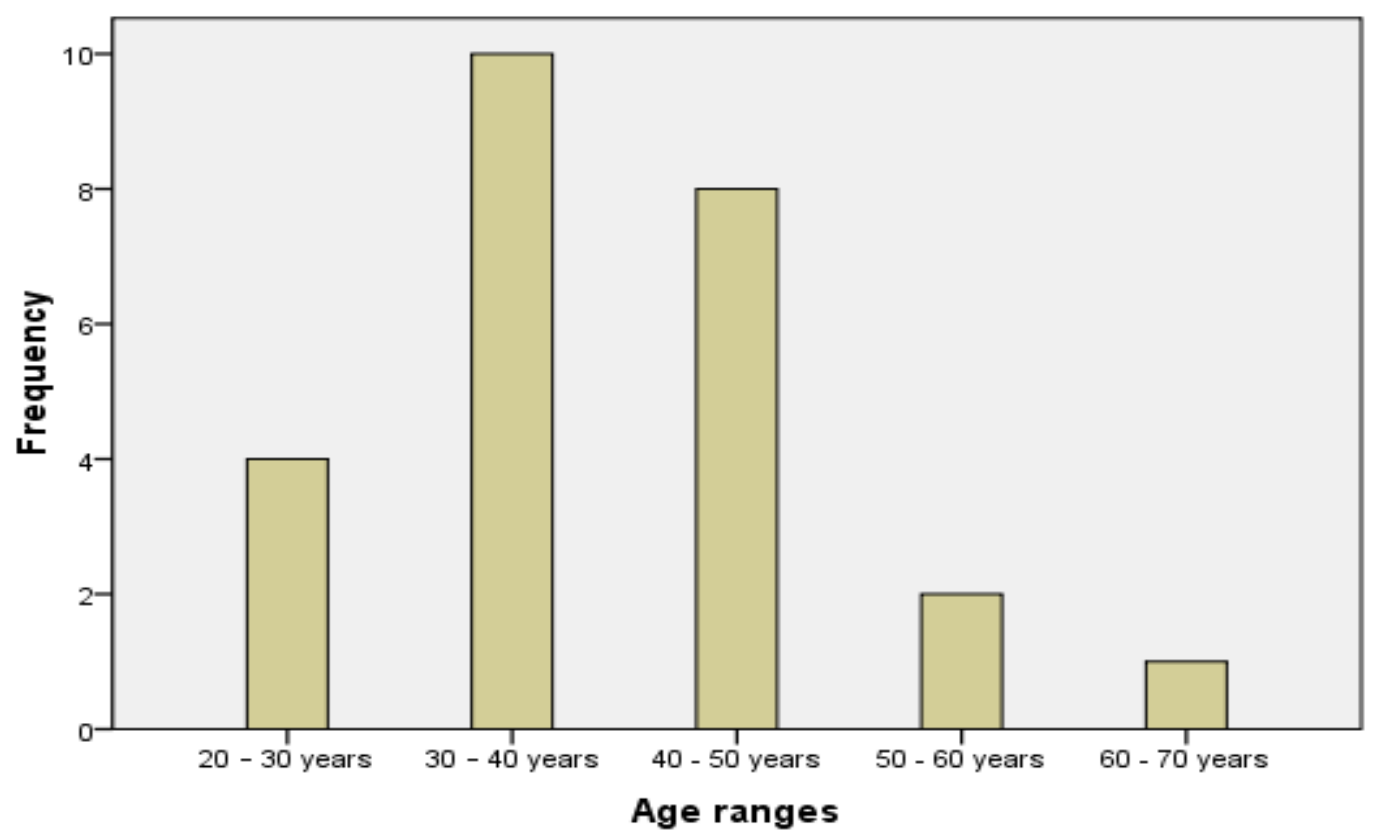




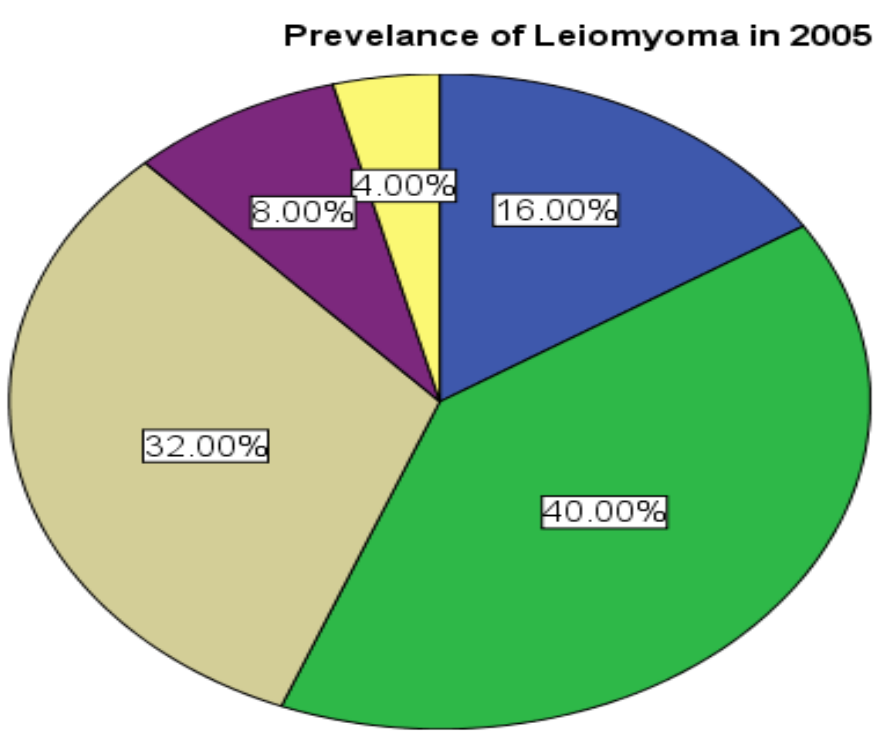

2005

$20-30$ years

30 - 40 years

40 - 50 years

50 - 60 years

$\square 60$ - 70 years

2006

\begin{tabular}{|ll|l|l|l|l|}
\hline & & Frequency & Percent & Valid Percent & $\begin{array}{l}\text { Cumulative } \\
\text { Percent }\end{array}$ \\
\hline Valid & $20-30$ years & 14 & 14.0 & 31.8 & 31.8 \\
& $30-40$ years & 12 & 12.0 & 27.3 & 59.1 \\
& $40-50$ years & 14 & 14.0 & 31.8 & 90.9 \\
& $50-60$ years & 4 & 4.0 & 9.1 & 100.0 \\
& Total & 44 & 44.0 & 100.0 & \\
Missing & System & 56 & 56.0 & & \\
Total & 100 & 100.0 & & \\
\hline
\end{tabular}

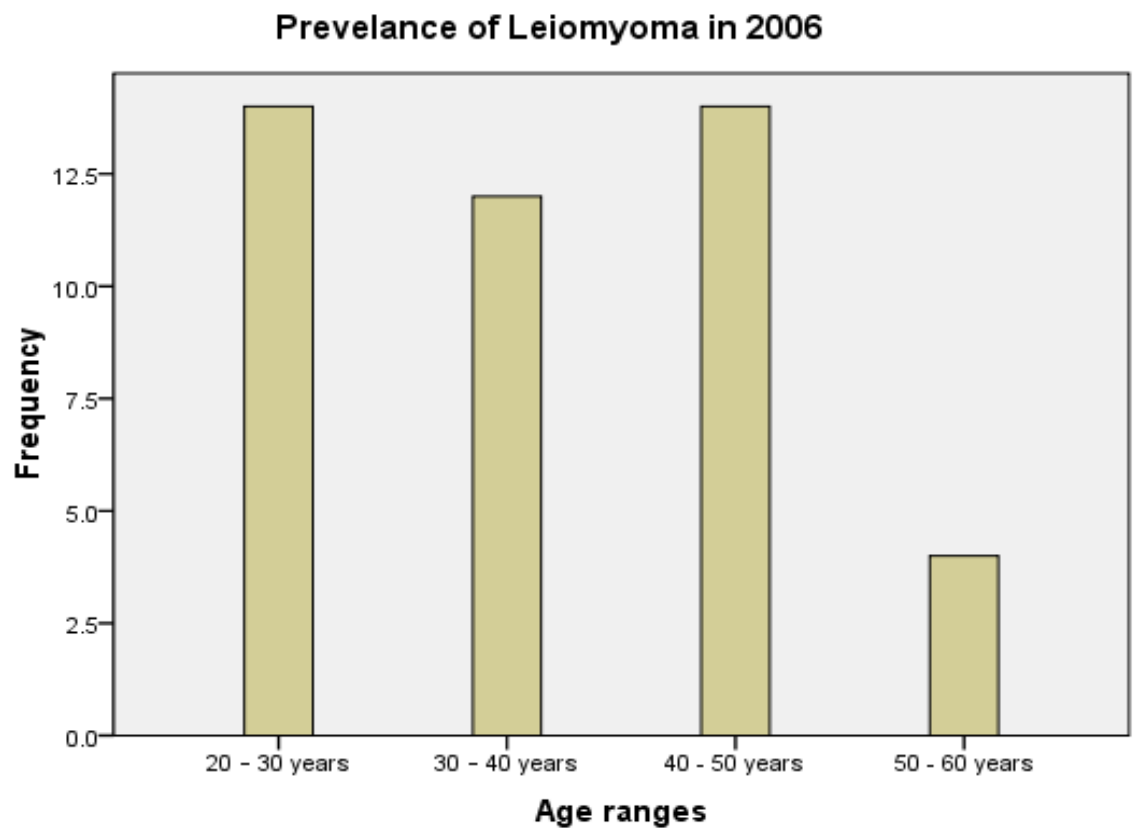




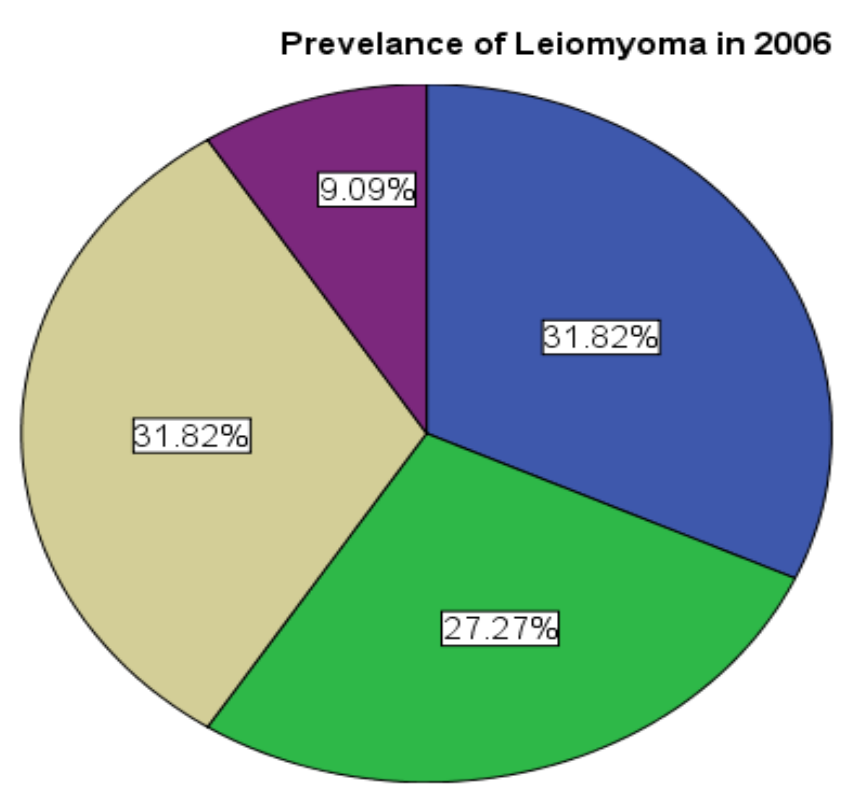

2006

$\square 20-30$ years

30 - 40 years

40 - 50 years

150 - 60 years

2007

\begin{tabular}{|ll|l|l|l|l|}
\hline & & Frequency & Percent & Valid Percent & $\begin{array}{l}\text { Cumulative } \\
\text { Percent }\end{array}$ \\
\hline Valid & $20-30$ years & 17 & 17.0 & 21.8 & 21.8 \\
& $30-40$ years & 36 & 36.0 & 46.2 & 67.9 \\
& $40-50$ years & 20 & 20.0 & 25.6 & 93.6 \\
& $50-60$ years & 5 & 5.0 & 6.4 & 100.0 \\
& Total & 78 & 78.0 & 100.0 & \\
Missing & System & 22 & 22.0 & & \\
Total & & 100 & 100.0 & & \\
\hline
\end{tabular}

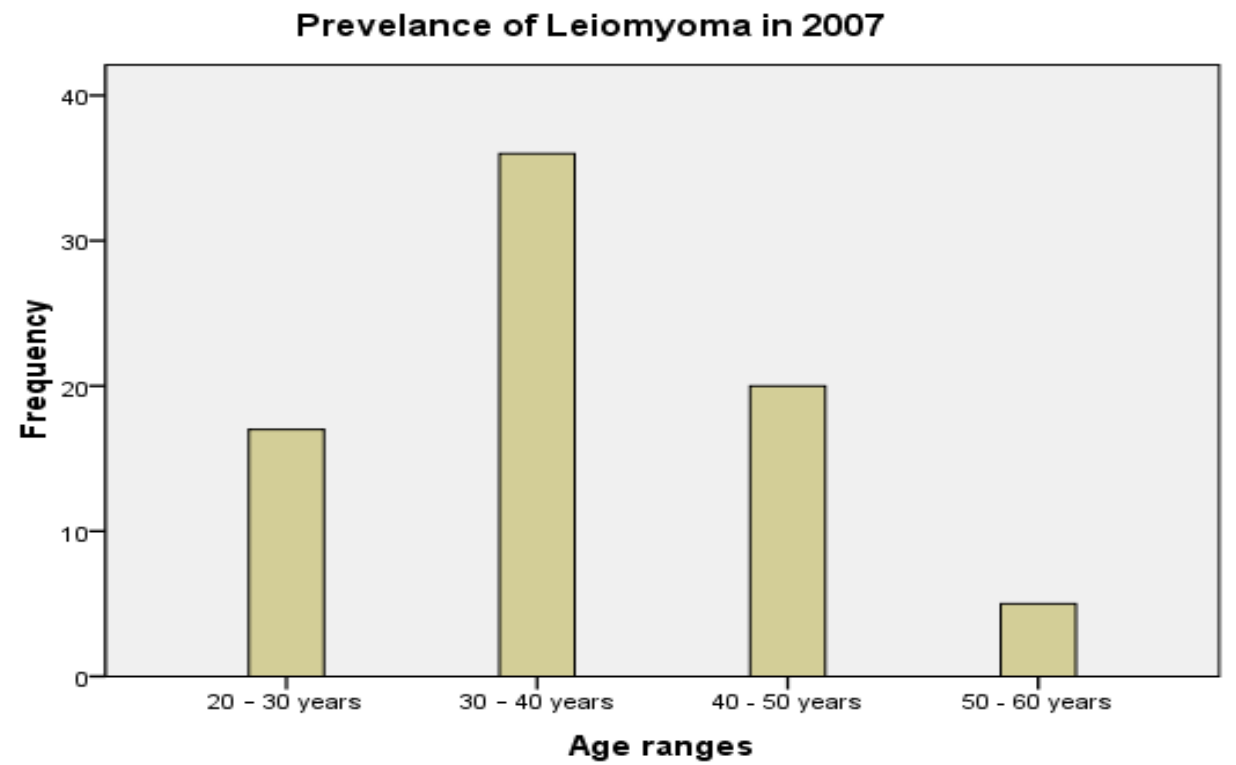




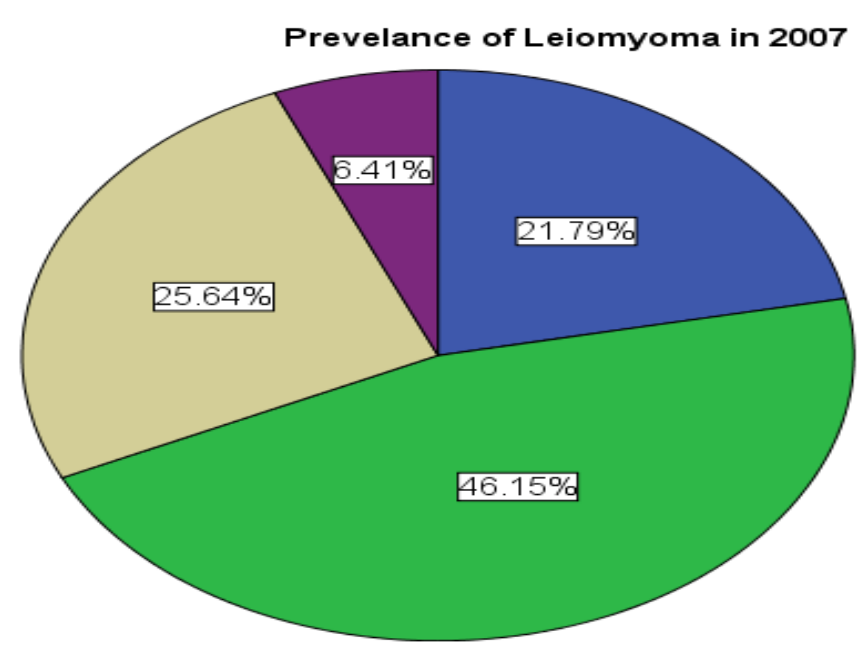

2007

$20-30$ years

$30-40$ years

$40-50$ years

2008

\begin{tabular}{|c|c|c|c|c|c|}
\hline & & Frequency & Percent & Valid Percent & $\begin{array}{l}\text { Cumulative } \\
\text { Percent }\end{array}$ \\
\hline \multirow[t]{7}{*}{ Valid } & $20-30$ years & 12 & 12.0 & 16.7 & 16.7 \\
\hline & $30-40$ years & 27 & 27.0 & 37.5 & 54.2 \\
\hline & $40-50$ years & 27 & 27.0 & 37.5 & 91.7 \\
\hline & $50-60$ years & 3 & 3.0 & 4.2 & 95.8 \\
\hline & $60-70$ years & 2 & 2.0 & 2.8 & 98.6 \\
\hline & Above 70 years & 1 & 1.0 & 1.4 & 100.0 \\
\hline & Total & 72 & 72.0 & 100.0 & \\
\hline Missing & System & 28 & 28.0 & & \\
\hline Total & & 100 & 100.0 & & \\
\hline
\end{tabular}

\section{Prevelance of Leiomyoma in 2008}

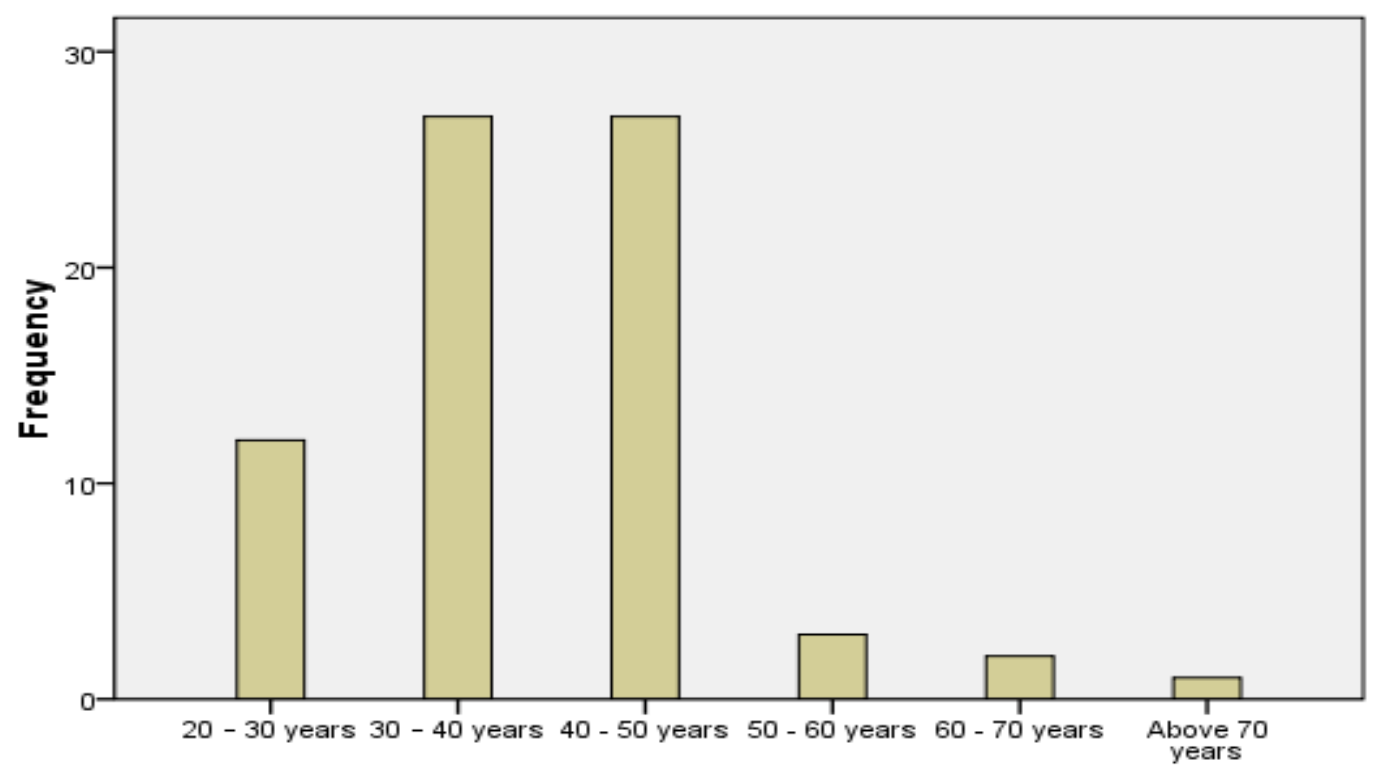

Age ranges 


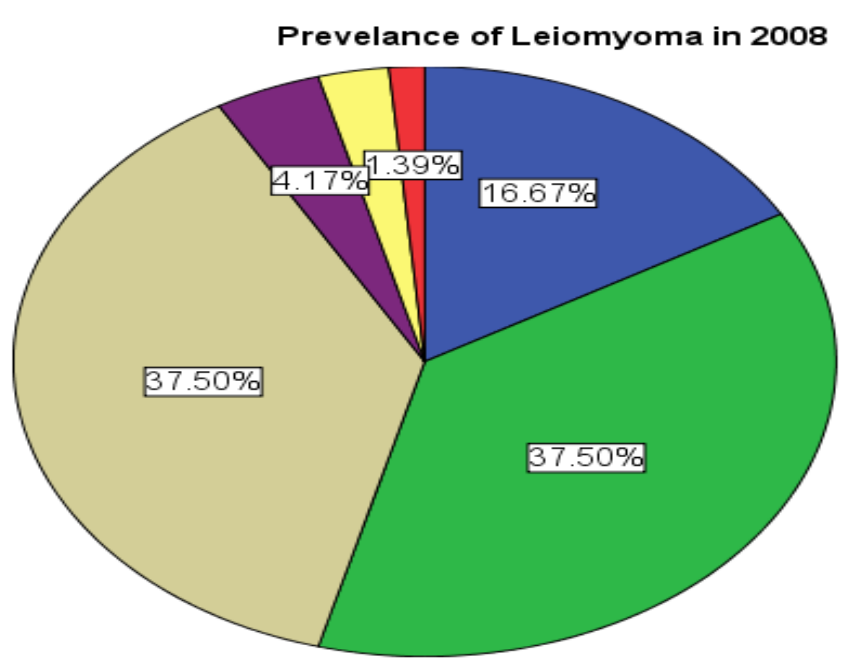

$20-30$ years

$30-40$ years

40 - 50 years

$60-70$ years

Above 70 years

2009

\begin{tabular}{|ll|l|l|l|l|}
\hline & & Frequency & Percent & Valid Percent & $\begin{array}{l}\text { Cumulative } \\
\text { Percent }\end{array}$ \\
\hline Valid & Under 20 years & 1 & 1.0 & 1.0 & 1.0 \\
& 20 - 30 years & 18 & 18.0 & 18.4 & 19.4 \\
& $30-40$ years & 39 & 39.0 & 39.8 & 59.2 \\
& $40-50$ years & 31 & 31.0 & 31.6 & 90.8 \\
& $50-60$ years & 8 & 8.0 & 8.2 & 99.0 \\
& $60-70$ years & 1 & 1.0 & 1.0 & 100.0 \\
& Total & 98 & 98.0 & 100.0 & \\
Missing & System & 2 & 2.0 & & \\
Total & & 100 & 100.0 & & \\
\hline
\end{tabular}

Prevelance of Leiomyoma in 2009

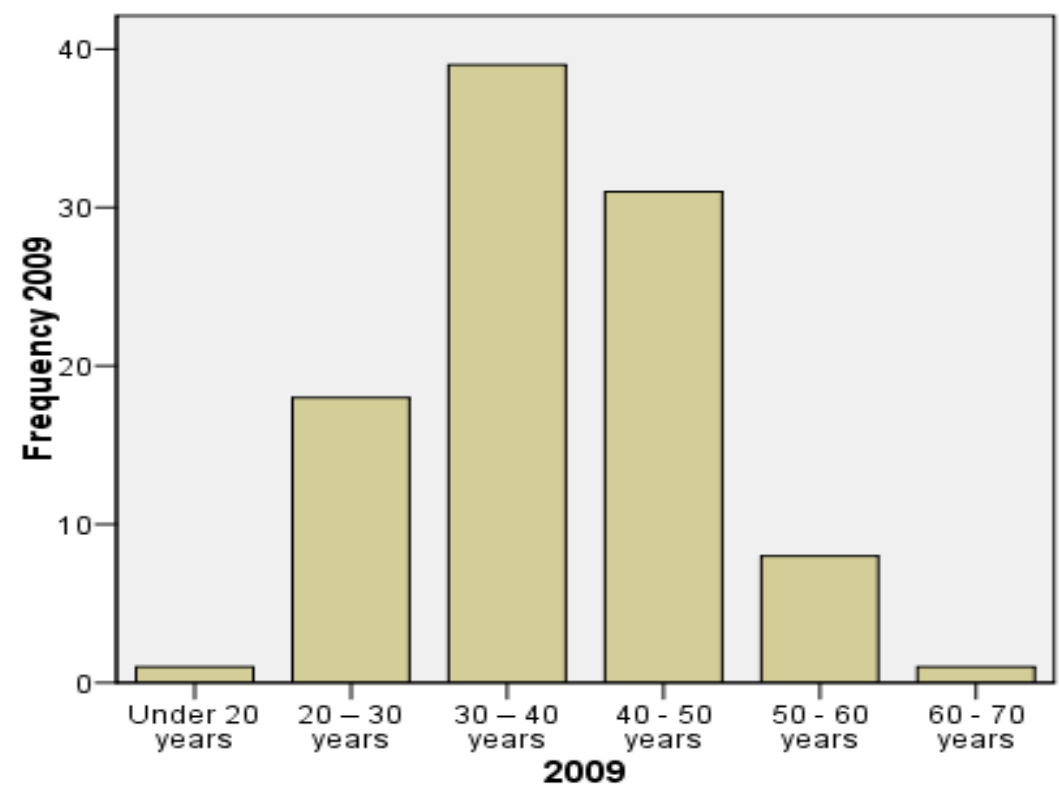




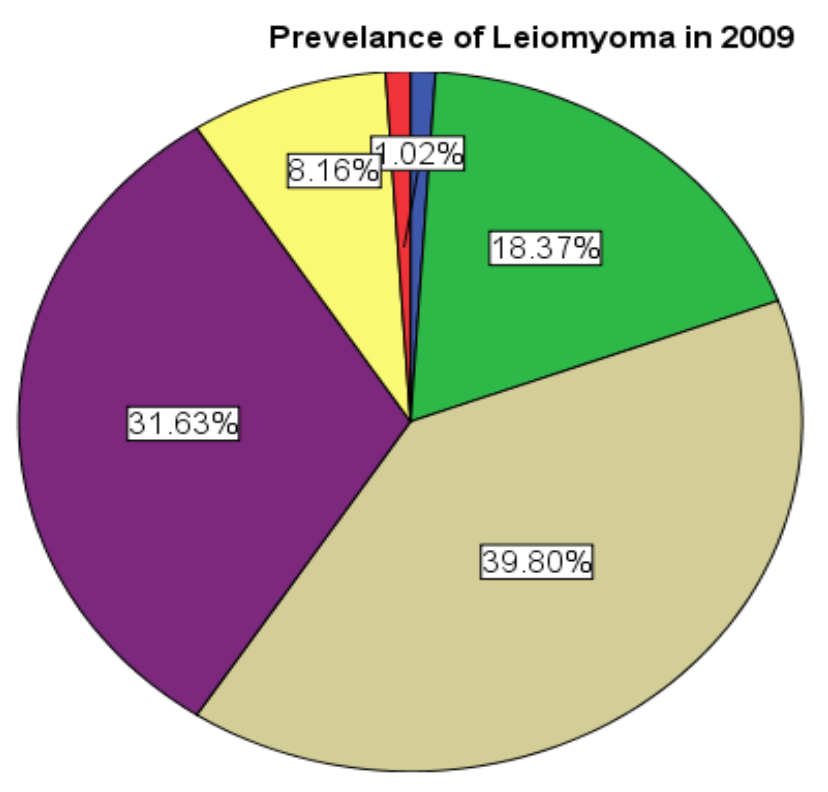

2009

$\square$ Under 20 years

$20-30$ years

$30-40$ years

40 - 50 years

$\square 50$ - 60 years

60 - 70 years

2010

\begin{tabular}{|ll|l|l|l|l|}
\hline & & Frequency & Percent & Valid Percent & $\begin{array}{l}\text { Cumulative } \\
\text { Percent }\end{array}$ \\
\hline Valid & Under 20 years & 3 & 3.0 & 3.3 & 3.3 \\
& 20 - 30 years & 7 & 7.0 & 7.8 & 11.1 \\
& $30-40$ years & 42 & 42.0 & 46.7 & 57.8 \\
& $40-50$ years & 30 & 30.0 & 33.3 & 91.1 \\
& $50-60$ years & 4 & 4.0 & 4.4 & 95.6 \\
& $60-70$ years & 3 & 3.0 & 3.3 & 98.9 \\
& 8 & 1 & 1.0 & 1.1 & 100.0 \\
& Total & 90 & 90.0 & 100.0 & \\
Missing & System & 10 & 10.0 & & \\
Total & & 100 & 100.0 & & \\
\hline
\end{tabular}

Prevelance of Leiomyoma in $\mathbf{2 0 1 0}$

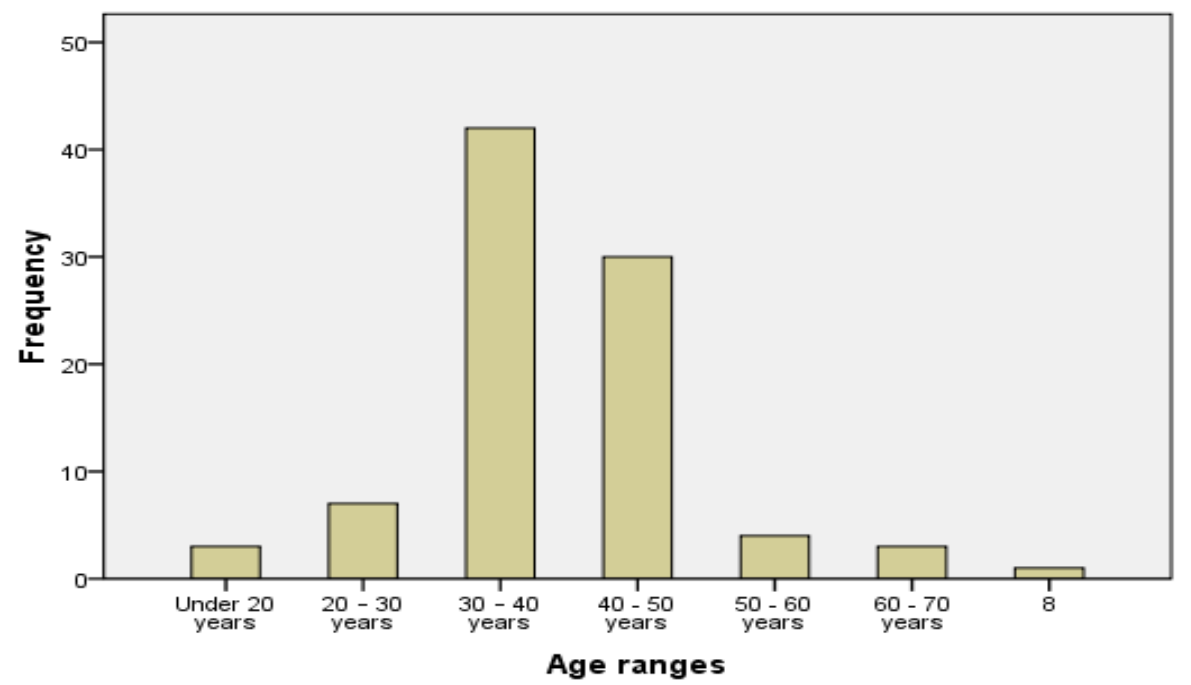




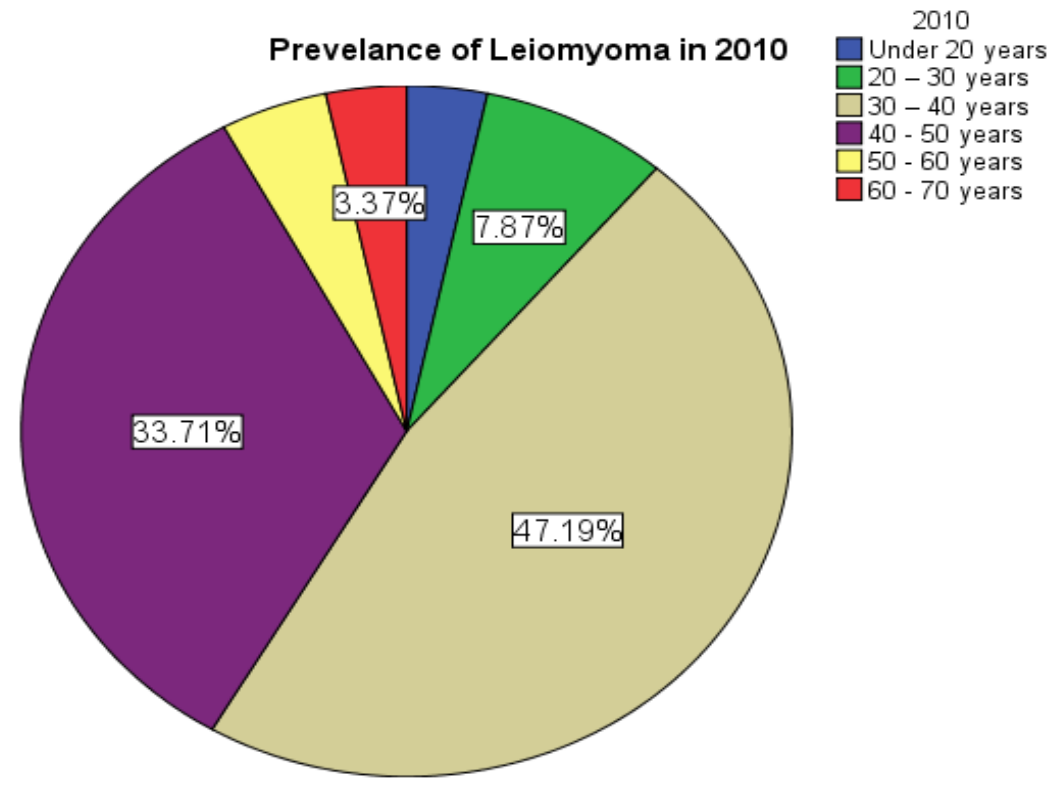

2011

\begin{tabular}{|ll|l|l|l|l|}
\hline & & Frequency & Percent & Valid Percent & $\begin{array}{l}\text { Cumulative } \\
\text { Percent }\end{array}$ \\
\hline Valid & Under 20 years & 1 & 1.0 & 1.2 & 1.2 \\
& 20 - 30 years & 10 & 10.0 & 11.6 & 12.8 \\
& $30-40$ years & 51 & 51.0 & 59.3 & 72.1 \\
& $40-50$ years & 19 & 19.0 & 22.1 & 94.2 \\
& $50-60$ years & 4 & 4.0 & 4.7 & 98.8 \\
& $60-70$ years & 1 & 1.0 & 1.2 & 100.0 \\
& Total & 86 & 86.0 & 100.0 & \\
Missing & System & 14 & 14.0 & & \\
Total & & 100 & 100.0 & & \\
\hline
\end{tabular}

Prevelance of Leiomyoma in 2011

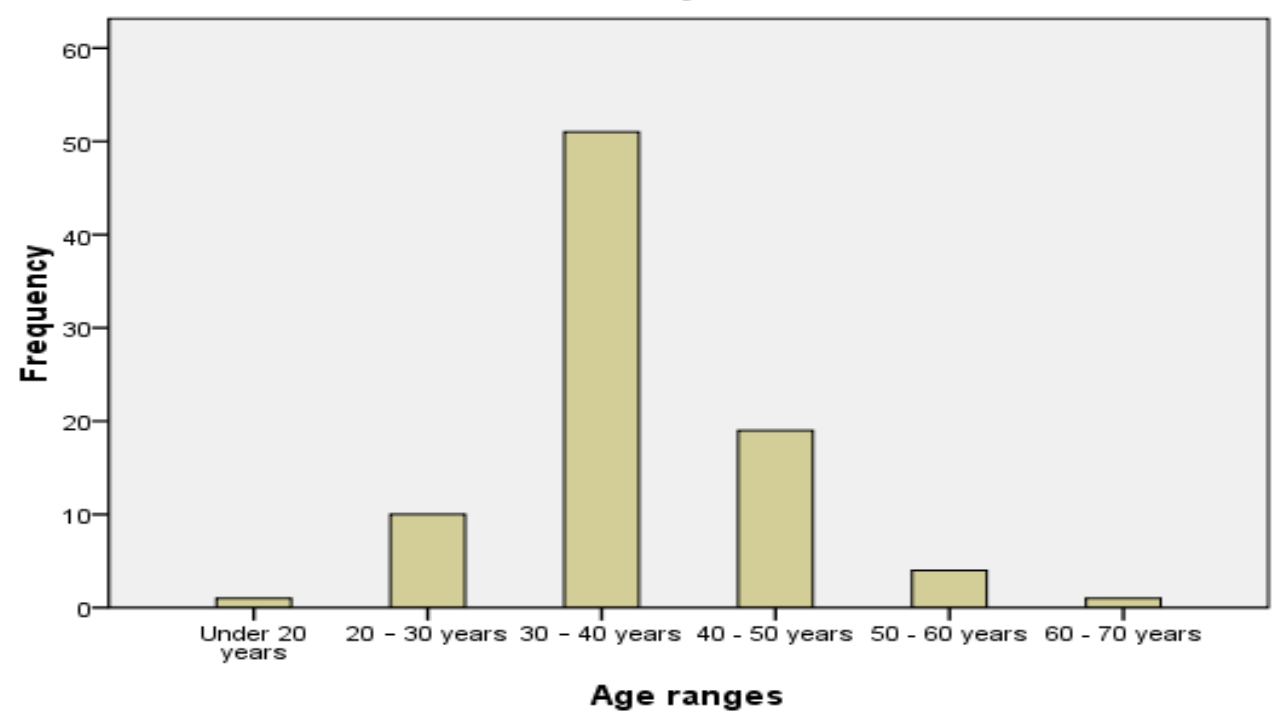




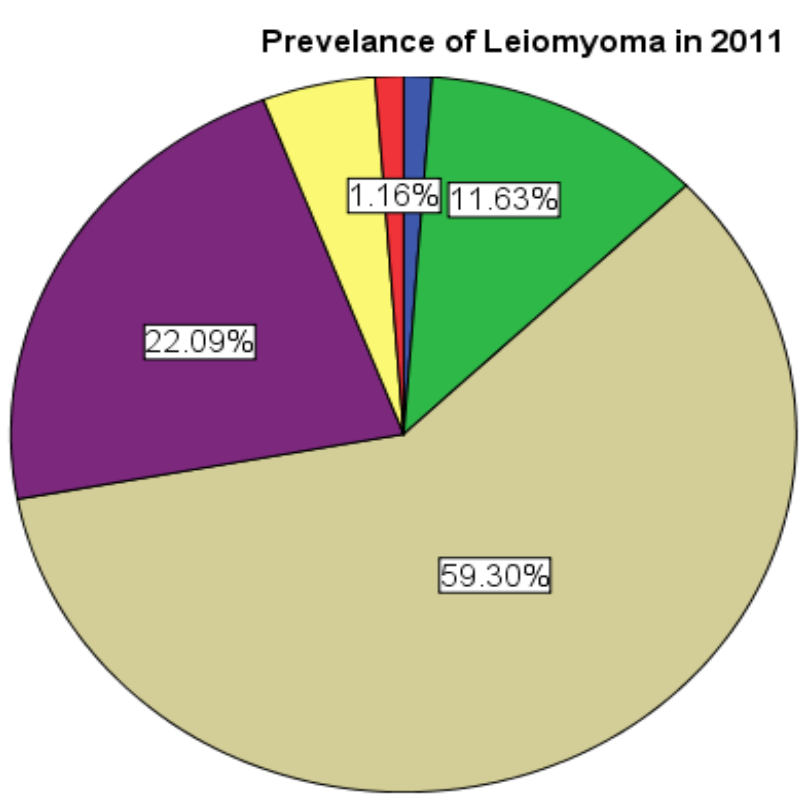

2011

Under 20 years

$20-30$ years

$30-40$ years

40 - 50 years

50 - 60 years

$\square 60$ - 70 years

2012

\begin{tabular}{|ll|l|l|l|l|}
\hline & & Frequency & Percent & Valid Percent & $\begin{array}{l}\text { Cumulative } \\
\text { Percent }\end{array}$ \\
\hline Valid & 20 - 30 years & 21 & 21.0 & 34.4 & 34.4 \\
& 30 - 40 years & 31 & 31.0 & 50.8 & 85.2 \\
& $40-50$ years & 9 & 9.0 & 14.8 & 100.0 \\
& Total & 61 & 61.0 & 100.0 & \\
Missing & System & 39 & 39.0 & & \\
Total & & 100 & 100.0 & & \\
\hline
\end{tabular}

Prevelance of Leiomyoma in 2012

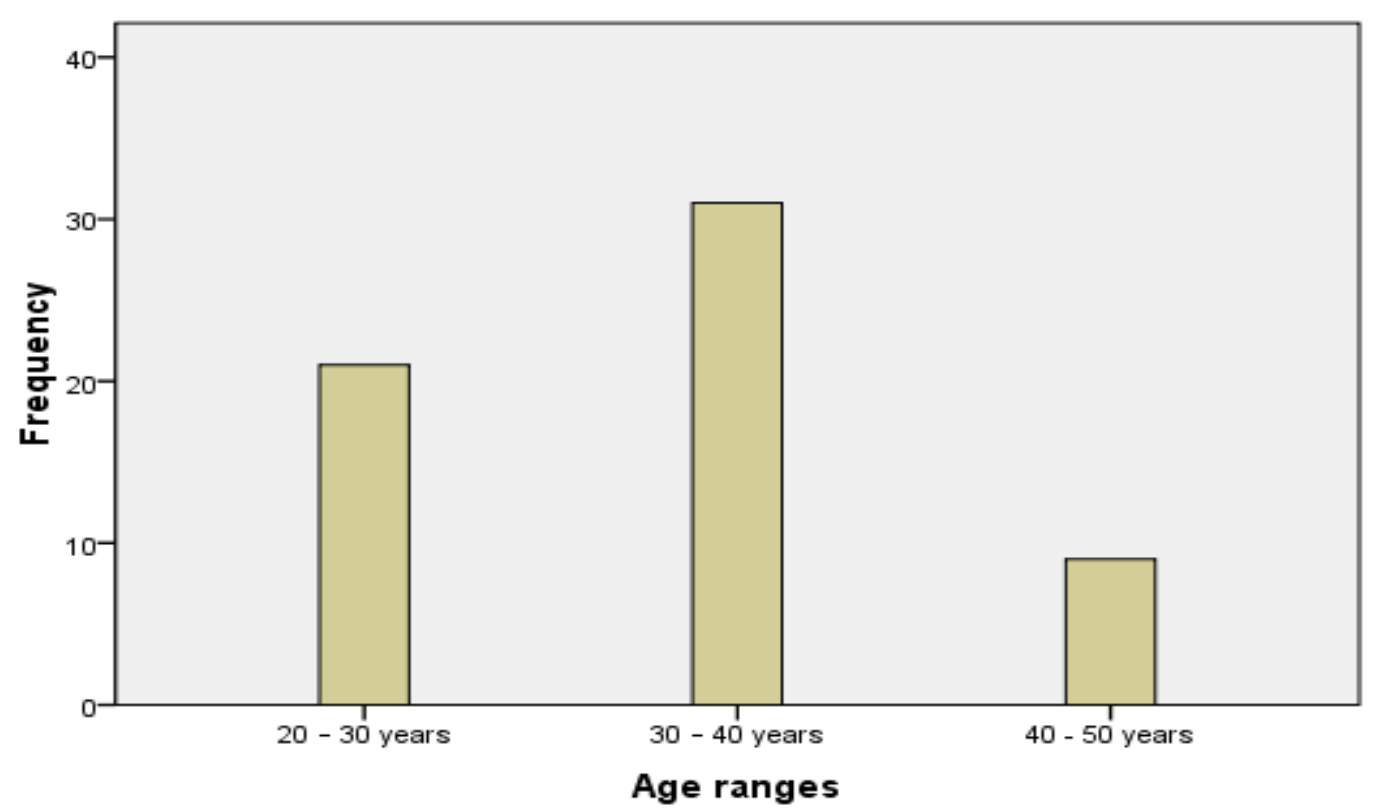




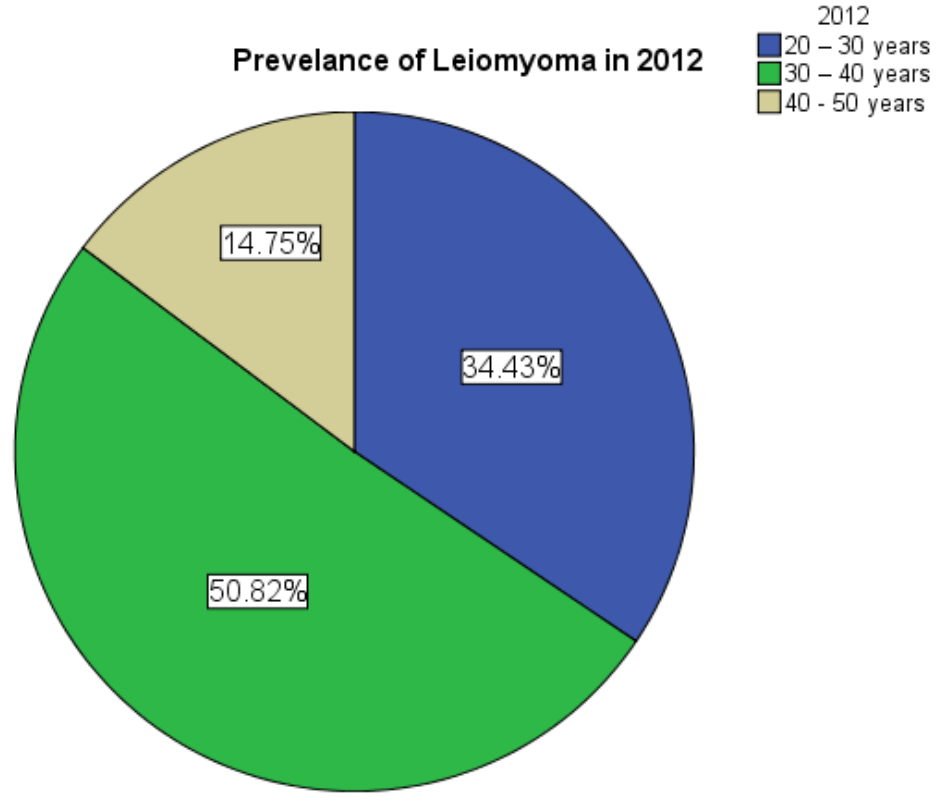

From the above representations, we could deduce the average age range of the predilection of this benign,solid tumor to be age ranges of 30- 40 and 40-50 years respectively. In all the years of the study, the most age range involved was 30-40 years as this falls within the fertility years of most black African women hence the search for the cause of infertility among this group of women; thus leading them to surgical removal of this lesion.

DISCUSSIONS: The general result seen from our study was that age range of 30-40 years are the worst hit of the benign, solid tumors. This is closely followed by 40-50 years. This result is similar to other studies like Carolyn $\mathrm{J}$ et al who reported that $66 \%$ of women before the reach age of 50 years are often diagnosed with this tumor. Also Day Baird D. et al noted in their study that this tumor is often seen in women of African descent and women who have not borne at ages of 30-45 years.

Other studies by Okolo S. ${ }^{27}$ and Wise L.A et $\mathrm{al}^{28}$ reported that most of these women starts to give symptoms of the tumor by age of 30 years to end of reproductive life. ${ }^{27,28}$ They noted that the tumor grows very slowly as this varies from individual to the next with about $90 \%$ of them ceasing to grow or regress after menopause. $^{21}$ These has attributed to be due to ER-beta, ER-alpha, and progesterone receptors been over expressed in pre menopausal fibroids. ${ }^{29,30-33}$

This is why myomectomy which is preferred surgery for women aged under 40 years are done as most are of low parity and have great desire to maintain fertility since there is a reasonably good chance of subsequent pregnancy. ${ }^{22,24,26}$ In few cases, myomectomy is also offered to women 40 years and above as in cases of primary infertility as to enable them achieve pregnancy through in vitro-fertilization(IVF) and embryo transfer. This is currently an innovative management for older women not yet pregnant.

Finally, it is adviceable that all women of reproductive age should undergo a thorough gynecologic and pelvic examination before any procedure. Also imaging of uterus using ultrasound or MRI as to evaluate sizes, location and numbers of fibroids. Other laboratory investigations like Full blood count, coagulation studies, metabolic profile and prothrombin test are done.

\section{Conclusions/Recommendation:}

Uterine leiomyoma remains benign lesion of public health importance in our environment.

It is necessary for all procedures and benefits to be explained to the patient in details. All hormonal therapies and surgical procedures-myomectomy,hysterectomy and embolization explained with consequent complications.

However, minimal invasive alternatives now available like laparoscopic management,endometrial ablations should be encouraged where they are available.

\section{References:}

[1]. Chen CR, Buck GM, Courey NG,Perez KM et al. Risk factors for uterine fibroids among women undergoing tubal sterilization. Am J.Epidemiol 2001;153:20-26.

[2]. Parker WH. Etiology,Symptomatology,and diagnosis of uterine myoma. FertilSteril 2007:87:725-736

[3]. Carolyn J. Hildreth,CassoLynon MA,Richard M. Glass. Uterine fibroids. JAMA 2009;301(1): 122.doi:10.1001/jama.301.1.122

[4]. Day Baird D,Dunson DB,Hill MC et al. High Cummulative incidence of uterine Leiomyoma in Black and white women. Ultrasound evidence. Am J. obstet. Gynaecol 2003;188:100-7 
[5]. Walker CL,Stewart EA. Uterine fibroids: The elephant in the room. Science 2005:308:1589-1592.

[6]. SemmK,Mettler L "Technical Progress in Pelvic Surgery via operative Laparscopy" American Journal via Operative Laparascopy" American Journal of obstretics\&Gynaecology. 1980,vol138,no.2,PP 121-127. View at scopus.

[7]. Wiler, Jennifer L. Diagnosis: Uterine Fibroids/Leiomyoma Emergency Medicine News: January 2008-vol30-issue1 P20 doi:10.1097/01.EEM.0000307648.29384.d4.

[8]. Mohamed Sabry,ayman Al-Hendy. Innovative oral Treatment of uterine Leiomyoma. Obstretics and Gynaecology International volume 2012 (2012),Article ID 943635,10 Pages doi:10.1155/2012/943635.

[9]. Ogedengbe O.K, "uterine fibroids" in contemporary obstretics and Gynaecology for developing countries,F. Okonofua and k.Odunsi,Eds;2003,PP202-213,Intec Printers Limited,Ibadan,Nigeria,Ist edition.

[10]. Akinyemi B.O,Adewoye B.R. et al; "uterine Fibroid a review," Nigeria Journal of Medicine,2004,vol13,no.4 PP 318-329.

[11]. Olatinwo A.W.O, Offiong R.A, "Ann analysis of Surgically treated cases of uterine fibroid at the university of Ilorin Teaching hospital,Ilorin,Nigeria, "Nigerian Journal of Surgically research 2002,vol92,PP6-11

[12]. Aboyeji A.P. et al. "uterine fibroids. A ten year clinical review at University of Ilorin Teaching hospital Ilorin Nigeria. "Nigeria Journal of Medicine 2002, vol 11,PP 16-19.

[13]. Durhan N-Current and emerging Treatments for uterine Myoma.-doi :http://dx.doi.org/10.214/IJWH.515710.2011 vol 3 pages 231 241.

[14]. McCluggage WG,ELLis PK,Mcchire N. Pathol.2000;19: 342-347.

[15]. Pelage JP, Guaou N, Jha R, Ascher S, Spies J. Uterine Fibroid tumors: Long Term MR imaging outcome after embolization. Radiology 2004;230:803-809.

[16]. Yousefi S,Czeyda- Pommershein F et al. Repeat uterine artery embolization: Indications and Technical Findings. J.Vanc .Interv. Radiol. 2006; 17: 1923-1929.

[17]. Colgan T J, Pron G, Mocarski EJM et al. Pathologic features of uteri and Leiomyoma following uterine artery embolization for Leiomyomas. Am J SurgPathol 2003;27:167-177.

[18]. Weichert W., Denkert c et al. Uterine arterial embolization with tris-acryl gelation microspheres: a histopathologic evaluation. Am J.SurgPathol 2005;29:955-961

[19]. Dutton S,Hirst A et al. A ukMulticentre retrospective cohort study comparing hysterectomy and uterine artery embolization for the treatment of symptomatic uterine fibroids (HOPEFUL STUDY): Main results on medium-term safety and efficacy. B JOG 2007;114:1340-1351.

[20]. Pron G., Mocarski E., Bennet J et al. Pregnancy after uterine artery embolization for Leimyomata: The Ontario multicenter Trail. ObstretGynecol 2005;105:67-76.

[21]. Lumsden M.A, "'Benign Disease of uterus", in Dew hurst's Textbook of obstretics and Gynaecology, D.K.edmonds,Ed; 2007,PP.636-644, Blackwell Publishing,London,Uk $7^{\text {th }}$ Edition.

[22]. Omole- ohonsi A and Ashimi O.A. "Non-emergency hysterectomy: Why the aversion?" Archives of Gynaecology and obstretics 2009,vol.280,No. 6,PP. 953-959.

[23]. Emebolu J.O, “ UterineFibrmyomata: Presentation and Mangement in Northern Nigeria, “ International Journal of Gynaecology and obstretics 1987,vol 25,No.5,PP 43-46.

[24]. Gehlbach D.L, Sonsa et al. “ abdominal Myomectomy in the Treatment of infertility, “ International Journal of Gynaecology and obstretics, 1993,Vol 40,No.1,PP 45-50.

[25]. Ezenwafor and Jimoh G, “ Abdominal hysterectomy at the university of Ilorin Teaching hospital,Ilorin. A 5 year review, "Nigeria hospital Practice 2007,vol 1,No.2 PP 45-49.

[26]. Balogun O.R and Nwachukwu C.N.D, Surgical Findings at Laparascopy for uterine fibroids in university of Ilorin Teaching hospital, " The Tropical Journal of health Sciences, 2006,vol.13,No.2,PP 27-30.

[27]. Okolo S, “ Incidence, aetiology and epidemiology of uterine fibroids, " best Practice and research: Clinical obstretics and Gynaecology. 2008.vol22, No.4 PP 571-588.

[28]. Wise LA, Palmer JR et al. "Age-Specific incidence rates for self-reported uterine Leiomyomata in the black women's health study," obstretics\& Gynaecology,2005.vol.105,No.3,PP.563-568.

[29]. Hodge JC and Morton CC, “ GeneticHeterogenity among uterine Leiomyomata: Insights into malignant Progression” Human molecular genetics,2007.vol 16, No1,PP R7-R13.

[30]. Shozu M, Murakami K et al. “ Aromatase and Leiomyoma of uterus, “ seminars in Reproductive Medicine, 2004,vol 22,No.1,PP5160 .

[31]. Bulun SE, Yang S et al. " Role of aromatase in endometrial disease, “ Journal of steroid Biochemistry and Molecular biology,2001,vol 79, No 1-5 PP 19-25.

[32]. Boynton R-Jarret, J. Rich Edwards et al, “ A prospective Study of Hypertension and risk of uterine Leiomyomata”. American Journal of Epidemiology,2005. Vol 161,No.7,PP 628-638.

[33]. Isobe A, Takeda et al., " Dual repressive effect of angiotensin 11 -type 1 receptor blocker temisartan on angiotensin 11-induced and estradiol- induced uterine Leiomyoma cell proliferation," Human reproduction 2008, vol 23, No 2,PP.440 -446. 